\title{
TRANSFER PRICING PADA ADARO ENERGY: PENDEKATAN ANALISIS FUNGSIONAL
}

\author{
Nicholas Jonathan Hendrik Wibowo \\ Universitas Katolik Widya Mandala Surabaya, Jl. Dinoyo 48A, Surabaya \\ *nicholas.jonathan@ymail.com
}

\section{A R T I C L E I N F O}

Article history:

Received July 9, 2020

Revised November 5, 2020

Accepted November 24, 2020

Key words:

Fiscal Policy, Corporate Tax Law, Indonesian Transfer Pricing, International Taxation

DOI:

https://doi.org/10.33508/jako.v13i1.2591

\begin{abstract}
A B S T R A C T
This research examines the funtional analysis in the case of Adaro Indonesia and Coaltrade as reported by Global Witness in order to explain the practicality of functional analysis and its relation to the fairness aspect of transfer pricing. This research was perpetrated using a descriptive qualitative method and utilised secondary data obtained from Global Witness' report and combined with other data from Adaro Energy's annual report in order to reduce bias in the analysis. In making the analysis, this research used secondary data analysis strategy and grounded theory approach in order to make a valid reasoning. In practice, functional analysis involved some process and identification including identification of entity involved, identification of perspective in the analysis, identification of relevant business process in terms of asset usage and business risk, and the classification of business models. The results show that the transfer pricing scheme in which Coaltrade served as full risk distributor indicated unfairness in the compensation since Coaltrade was able to earn more profit than Adaro Indonesia despite the low risk nature of the business. In that sense, functional analysis is related to the fairness aspect of transfer pricing in some way in regards that functional analysis enables analyst to get the big picture on the compensation earned by each entity invovled. An indication of unfair transfer pricing and tax evasion may arise in the case that a lower risk entity earns more than the higher risk one.
\end{abstract}

\begin{abstract}
A B S T R A K
Penelitian ini mengkaji analisis fungsional pada kasus Adaro Indonesia dan Coaltrade yang dilaporkan oleh Global Witness dengan tujuan untuk menjelaskan analisis fungsional dan kaitannya dengan aspek kewajaran dari transfer pricing. Penelitian ini dilakukan dengan metode deskriptif kualitatif dan menggunakan data sekunder yang diperoleh dari laporan Global Witness yang digabungkan dengan data lainnya dari laporan tahunan Adaro Energy untuk mengurangi bias dalam analisis. Analisis data dalam penelitian ini menggunakan strategi analisis data sekunder dan pendekatan grounded theory agar menghasilkan penalaran yang valid. Analisis fungsional, dalam prakteknya, melibatkan beberapa proses dan identifikasi antara lain identifikasi entitas yang terlibat, identifikasi perspektif dalam analisis, identifikasi proses bisnis yang relevan dalam hal penggunaan aset dan risiko bisnis, serta klasifikasi model bisnis. Hasil penelitian menunjukkan bahwa skema transfer pricing dimana Coaltrade berperan sebagai full risk distributor mengindikasikan ketidakwajaran dalam perolehan kompensasi dimana Coaltrade memperoleh keuntungan lebih banyak daripada Adaro Indonesia meskipun sifat bisnisnya berisiko lebih rendah. Analisis fungsional terkait dengan aspek kewajaran transfer pricing. Analisis fungsional dapat memberikan gambaran tentang tingkat kompensasi wajar yang diperoleh oleh setiap entitas yang terlibat. Indikasi skema transfer pricing yang tidak wajar dan penggelapan pajak dapat muncul dalam kasus di mana entitas dengan risiko lebih rendah mendapatkan lebih banyak laba daripada entitas afiliasi berisiko yang lebih tinggi.
\end{abstract}




\section{PENDAHULUAN}

Harga Transfer (Transfer Pricing) adalah penetapan harga oleh Wajib Pajak dalam menjual, membeli, atau berbagi sumber daya dengan afiliasinya (Arnold dan McIntyre, 2002) dalam semua transaksi dengan pihak berelasi yang mencakup penjualan barang berwujud maupun tidak berwujud, layanan, pembiayaan, dan lain sebaginya (Mehafdi, 2000) serta biasanya ditandai oleh hubungan khusus antar perusahaan yang melakukan transaksi (Setiawan, 2014). Transfer pricing seringkali dimaknai secara negatif (pejorative) sebagai teknik minimalisasi pajak yang melibatkan manipulasi harga barang atau jasa untuk memindahkan laba antar entitas (Butterworths, 1997). Dalam hal tersebut, praktik transfer pricing biasanya ditujukan untuk mengurangi jumlah penghasilan kena pajak terutang (Darussalam, Septriadi, dan Kristiaji, 2013) sambil mengalokasikan pendapatan ke yurisdiksi dengan tarif pajak yang lebih rendah dan/atau mengalokasikan biaya yang dapat dikurangkan dari pajak ke yurisdiksi yang memiliki tarif pajak lebih tinggi (Darussalam dan Ngantung, 2013). Perusahaan pada umumnya selalu berusaha meminimalisasi beban pajak serendah mungkin (Van den Hurk, 2014), dan perbedaan dalam tarif pajak di berbagai negara cenderung mendorong perusahaan multinasional (MNE) untuk menggunakan transfer pricing melalui penciptaan harga palsu (Horst, 1971). Akibatnya, otoritas pajak biasanya mencurigai adanya praktik pemindahan laba melalui harga transfer di transaksi pihak berelasi. Padahal, transfer pricing tidak hanya bermakna negatif namun juga dapat dimaknai secara positif untuk berbagai tujuan lainnya, seperti alokasi sumber daya, optimalisasi laba, motivasi, dan evaluasi kinerja suatu fungsi (Mehafdi, 2000).

Di Indonesia, beberapa penelitian telah mengkaji permasalahan yang ada pada praktik transfer pricing dalam negeri dengan akar permasalahan yang tumpang tindih. Penelitian oleh Dewi dan Mustikasari (2020) menyimpulkan bahwa permasalahan praktik transfer pricing secara pejorative di Indonesia seringkali didasari oleh rendahnya kesadaran Wajib Pajak, etika dan i'tikad yang rendah. Rendahnya kesadaran Wajib Pajak, etika, dan i'tikad yang rendah ini berasal dari adanya tujuan untuk memaksimalkan laba dan mengurangi biaya pajak, khususnya bagi perusahaan multinasional (Huda, Nugraheni, dan Kamarudin, 2017). Namun, penelitian deskriptif kualitatif oleh Saraswati, Saifi, dan Dwiatmanto (2014) malah menemukan bahwa skema penetapan harga transfer dengan metode Transnational Net Margin Method (TNMM) pada pe- rusahaan yang diteliti sejatinya telah sesuai dan wajar menurut peraturan yang berlaku (PER-32), namun kewajarannya masih diperdebatkan oleh pihak DJP sebagai otoritas pajak. Temuan ini membuktikan bahwa permasalahan praktik transfer pricing tidak hanya terpusat pada masalah etika Wajib Pajak saja, namun juga kurangnya Sumber Daya Manusia di DJP dalam memahami aspek kewajaran transfer pricing itu sendiri (Huda, Nugraheni, dan Kamarudin, 2017). Dapat disimpulkan bahwa permasalahan transfer pricing di Indonesia seringkali berupa perbedaan pendapat antara Wajib Pajak dan pihak DJP yang berakar dari tingginya kompleksitas transfer pricing itu sendiri, permasalahan etika Wajib Pajak, dan rendahnya pemahaman aspek kewajaran oleh Sumber Daya Manusia (SDM) yang terlibat, bahkan oleh pihak otoritas pajak sekalipun.

Perdebatan antara Wajib Pajak dan pihak otoritas pajak (DJP) dalam dunia praktik transfer pricing di Indonesia ini seringkali membahas aspek kewajaran transfer pricing itu sendiri dikarenakan kompleksitasnya yang begitu tinggi dan rendahnya pemahaman pihak-pihak yang terlibat di dalamnya. Padahal, aspek kewajaran transfer pricing di Indonesia berkiblat hanya kepada Arm's Length Principle (ALP) yang berfokus pada pemberian kompensasi wajar kepada setiap entitas yang terlibat dalam suatu transaksi afiliasi sehingga harga mencerminkan kekuatan pasar yang dipengaruhi oleh hukum permintaan dan penawaran (Setiawan, 2014). Meskipun demikian, penetapan kompensasi dan harga yang wajar ini tidaklah mudah dan sering menyebabkan kontroversi dengan pihak otoritas perpajakan (Lebowitz, 2000). Aspek kewajaran yang dipermasalahkan ini mencakup penetapan transfer pricing, pengaplikasian metode transfer pricing, dan pengukuran kewajaran transaksi melalui penggunaan transaksi pembanding (Saraswati, Saifi, dan Dwiatmanto, 2014) yang hanya merupakan bagian dari analisis kesebandingan. Analisis kesebandingan sendiri merupakan serangkaian langkah analisis, mulai dari identifikasi detail transaksi afiliasi, identifikasi pembanding potensial berdasarkan faktor-faktor kesebandingan, aplikasi metode transfer pricing untuk melakukan perbandingan, hingga pengukuran kewajaran dari dua transaksi yang diperbandingkan (Irawan, Febby, dan Kristiaji, 2013). Sejatinya, analisis kesebandingan akan rancu apabila tidak mengacu pada analisis fungsional yang tepat karena gambaran yang jelas terhadap fungsi tiap entitas yang terlibat dalam transaksi afiliasi hanya dapat diperoleh dari analisis fungsional (Irawan, Febby, 
dan Kristiaji, 2013). Dalam hal ini, analisis fungsional seringkali luput dari perhatian dan seharusnya memiliki urgensi tinggi untuk dikaji dalam literatur transfer pricing.

Penelitian ini bertujuan untuk mengkaji analisis fungsional pada kasus transfer pricing kontemporer Adaro dan Coaltrade pada laporan Global Witness, organisasi nirlaba/non-profit organisation (LSM/NGO) yang memerangi eksploitasi sumber daya dan korupsi. Adanya penelitian ini ditujukan untuk menjelaskan analisis fungsional dan kaitannya dalam menelaah aspek kewajaran transfer pricing melalui analisis kasus kontemporer di bidang studi transfer pricing. Selain itu, penelitian ini juga menawarkan kebaharuan dalam studi transfer pricing dimana kajian dalam penelitian ini berfokus pada analisis fungsional, sebuah topik yang masih tergolong jarang dalam studi transfer pricing di Indonesia. Penelitian ini bermanfaat akademis bagi bidang studi perpajakan khususnya transfer pricing dimana penelitian ini memberikan gambaran yang jelas atas penerapan analisis fungsional untuk mengkaji kewajaran dari skema transfer pricing melalui analisis kasus kontemporer. Terlebih lagi, penelitian ini juga bermanfaat praktis dalam membantu para praktisi memahami unsur kewajaran dari transfer pricing sehingga dapat mengambil langkah yang tepat dan mengurangi perdebatan. Penggunaan kasus transfer pricing kontemporer dalam penelitian ini disyaratkan agar hasil analisis dapat merefleksikan kondisi praktis yang ada guna meningkatkan manfaat praktis dari penelitian ini.

\section{KAJIAN LITERATUR DAN PENGEMBANGAN HIPOTESIS}

\section{Kajian Literatur}

Penelitian ini menggunakan Undang-Undang Perpajakan Indonesia tentang transfer pricing sebagaimana diatur dalam Pasal 18 (3) UU PPh (Undang-Undang Pajak Penghasilan, 2008) dan PER-32 (2011) guna menjelaskan peraturan yang mengatur transfer pricing di Indonesia. Selain itu, penelitian ini juga mengacu pada konsep analisis fungsional sebagai literatur utama dan dasar untuk meninjau analisis fungsional dan kaitannya terhadap kewajaran skema transfer pricing Adaro dan Coaltrade seperti yang dilaporkan oleh Global Witness (2019). Pemahaman terhadap konsep transfer pricing di Indonesia dan kajian tentang analisis fungsional ini merupakan hal yang integral dan diperlukan guna memahami alur logis, langkah-langkah, dan peraturan yang mengatur transfer pricing dan kewajarannya di Indonesia.
Konsep Transfer Pricing di Indonesia

Indonesia adalah salah satu negara di Asia yang pertama kali mengatur tentang harga transfer (Feinschreiber dan Kent, 2012) di mana regulasi berpusat pada hubungan khusus antar entitas. Kondisi untuk adanya hubungan khusus didasarkan pada Pasal 18 (4) UU PPh (2008). Setelah diyakini adanya hubungan khusus, Pasal 18 (3) memberikan kewenangan kepada DJP untuk menetapkan kembali utang sebagai ekuitas, jumlah penghasilan kena pajak, dan pengeluaran yang dapat dikurangkan untuk transaksi antara wajib pajak dengan pihak yang memiliki hubungan khusus sesuai dengan Arm's Length Principle (ALP). Hal ini menjadikan Indonesia memiliki lingkungan pemeriksaan pajak yang agresif yang sebagian didorong oleh keinginan Pemerintah Indonesia untuk meningkatkan penerimaan negara dari pajak (Ernst and Young Global, 2018).

Pengaturan kewajaran skema penetapan transfer pricing antar wajib pajak dengan hubungan khusus, Indonesia berkiblat pada ALP yang diatur dalam Pasal 18 (3) UU PPh (2008) dan PER-43 (diamandemen oleh PER-32, 2011), yang merupakan dasar bagi DJP untuk menilai penerapan ALP dan menentukan kewajaran transaksi yang tercantum dalam dokumen pendukung yang diatur dalam Peraturan Menteri Keuangan Nomor PMK.213/PMK.03/2016 (2016). ALP dalam praktiknya, berpatok pada konsep bahwa setiap transaksi harus didasarkan pada kompensasi yang wajar kepada masing-masing pihak. Kompensasi yang diperoleh pihak-pihak dengan hubungan khusus harus sebanding dengan pihak-pihak yang bertransaksi tanpa adanya hubungan khusus tersebut karena kompensasi dan harga yang wajar seharusnya ditentukan oleh kekuatan pasar yang memperhitungkan permintaan dan penawaran, sehingga transaksi tersebut mencerminkan harga pasar yang wajar (Setiawan, 2014). Meskipun demikian, penetapan kompensasi dan harga yang wajar ini tidaklah mudah dan sering menyebabkan kontroversi dengan pihak otoritas perpajakan (Lebowitz, 2000). Dalam hal ini, kompensasi yang sebanding belum tentu mencerminkan sebuah skema transfer pricing yang wajar karena kompensasi tersebut belum tentu mencerminkan kualitas barang/jasa yang sama, wajar, dan diberikan oleh entitas dengan fungsi serupa. Untuk menangani kontroversi tersebut, Pasal 18 (3) (UU PPh, 2008) dan PER32 (2011) mensyaratkan bahwa analisis kesebandingan dalam ALP harus diikuti dan dicerminkan melalui analisis fungsional dan pemilihan metode transfer pricing yang wajar dan sesuai. 
Analisis Fungsional dalam Transfer Pricing

Analisis fungsional, faktor pertama dalam ALP, adalah titik awal sebelum pemilihan Metode TP yang sesuai dan merupakan dasar dalam setiap analisis kewajaran harga transfer (Prescott-Haar, 2008). Analisis fungsional ini penting karena mampu memberikan gambaran dalam menentukan jumlah kompensasi yang wajar untuk setiap entitas yang terlibat. Analisis fungsional melibatkan beberapa langkah proses dimana setiap proses memiliki tujuannya masing-masing dan harus dilakukan agar hasil analisis dapat dipergunakan secara tepat dalam analisis berikutnya.

Sebagai langkah awal, analisis fungsional dapat dilakukan dengan cara mengidentifikasi seluruh entitas yang terlibat dalam kesatuan supply chain untuk mendapatkan gambaran awal dari fungsi atau kontribusi yang diberikan oleh sebuah entitas (Huibregtse, Verdoner, dan Welvaert, 2009). Proses selanjutnya adalah menentukan perspektif yang digunakan dalam membuat analisis fungsional dimana ada dua perspektif yang diperbolehkan: perspektif makro dan perspektif transaksi terkait (Irawan, 2013). Perspektif makro biasanya digunakan untuk melihat peran suatu entitas dalam value chain group. Dengan menggunakan perspektif ini, peran dan karakteristik suatu entitas dapat langsung diidentifikasi. Namun perspektif yang berbeda harus digunakan apabila sebuah entitas memiliki fungsi dan peran dalam transaksi afiliasi yang berbeda jauh dengan perannya secara umum dalam value chain group. Untuk menganalisis transaksi afiliasi ini, penggunaan perspektif transaksi terkait lebih tepat. Hal ini dikarenakan perspektif transaksi terkait berfokus langsung pada transaksi tersebut. Biasanya perspektif ini digunakan pada value chain grup yang memiliki penugasan langsung kepada entitas-entitas yang dibawahinya atau bisa juga digunakan oleh struktur organisasi berbentuk konglomerasi yang memiliki kompleksitas yang tinggi. Identifikasi perspektif ini penting karena dapat menentukan cakupan analisis yang harus dilakukan yang akan berpengaruh pada efisiensi usaha dan akurasi hasil.

Setelahnya, barulah analis berlanjut pada identifikasi proses bisnis yang relevan yang menelaah jenis risiko yang ditanggung dan jenis aset yang dipergunakan oleh sebuah entitas dalam suatu transaksi afiliasi. Penggunaan jenis aset, dalam proses identifikasi aset, harus diperhatikan karena penggunaan aset berupa pabrik dan perlengkapan, aset tidak berwujud seperti kekayaan intelektual, maupun aset keuangan seperti deposito, investasi saham, dan investasi obligasi masing-masing memiliki tingkatan kompensasi yang tingkatan risiko yang berbeda yang melekat pada aktivitas penggunaan aset tersebut. Proses identifikasi ini merupakan proses yang vital karena berpengaruh dalam menentukan harga transfer dan mengukur potensi kerugian yang dapat timbul serta dapat dipergunakan sebagai dasar dalam mencari transaksi pembanding.

Setelah proses identifikasi, tiap-tiap entitas diklasifikasikan ke dalam tiga model bisnis utama: manufaktur/produsen, distributor, atau penyedia jasa/layanan. Masing-masing klasifikasi usaha tersebut dibagi lagi ke dalam beberapa jenis sesuai dengan kompleksitas fungsi yang dijalankan serta risiko yang mengikuti aktivitas operasionalnya tersebut (Przysuski dan Lalapet, 2005). Pada klasifikasi bisnis manufaktur seperti pada halnya PT Adaro Indonesia, terdapat empat skema berbasis risiko dan kepemilikan barang yaitu toll manufacturer, contract manufacturer, licensed manufacturer, dan fully-fledged manufacturer dimana fully-fledged manufacturer memiliki tanggung jawab penuh dari pengolahan material hingga kepemilikan legalitas barang dan kepemilikan merk dagang dalam bentuk aset tidak berwujud. Di sisi lain, klasifikasi usaha distribusi, seperti halnya pada Coaltrade, hanya memiliki dua skema saja yaitu sales representative/sales agent dan full-risk distributor dimana full-risk distributor bertanggung jawab penuh dari pembelian barang hingga penjualan dan terpapar pada risiko persediaan dan risiko pasar sekaligus. Penerimaan kompensasi yang wajar pada entitasentitas ini harus didasarkan kepada tanggung jawab dan risiko yang ditanggung oleh entitas tersebut. Dalam hal ini, entitas yang menanggung risiko yang sangat besar seperti fully-fledged manufacturer tentunya akan memiliki tingkatan kompensasi yang sangat besar juga untuk kontribusinya. Hasil dari analisis fungsional ini mampu memberikan gambaran yang jelas mengenai sejauh mana fungsi (beserta risiko dan aset yang melekat) dari transaksi independen telah sebanding dengan transaksi afiliasi yang dianalisis (Irawan, Febby, dan Kristiaji, 2013). Dalam hal ini, analisis fungsional memungkinkan pengkategorian tingkatan dan kedudukan suatu transaksi pembanding dalam mata rantai suplai produksi.

\section{METODE PENELITIAN}

Penelitian ini merupakan penelitian deskriptif kualitatif, paradigma penelitian yang berfokus pada pemahaman masalah sosial (social situation) berdasarkan kondisi riil yang sebenarnya dan 
menekankan pada sifatnya yang holistik, kompleks dan rinci (Arikunto, 2016). Data yang digunakan dalam penelitian ini bersifat sekunder, yang tidak didapatkan dari sumber utama, melainkan melalui pengumpulan dan pengkajian data dari sumber lain sehingga penelitian merupakan pihak kedua yang mengelola dan mengkritisi data tersebut (Moleong, 2017). Data didapatkan dari laporan tahunan Adaro Energy 2008 dan dari laporan Global Witness (2019) "Indonesia's shifting coal money, Part 3: Taxing Times for Adaro". Dalam melakukan analisisnya, peneliti menggunakan strategi analisis data sekunder dimana data sekunder yang ada dikaji lebih lanjut guna mengevaluasi atau menelaah kembali hasil yang telah ada. Dalam melakukan analisis data sekunder, analisis dan pembentukan argumen didukung data faktual berupa laporan keuangan Adaro Energy sendiri untuk tahun-tahun yang bersangkutan dan juga konsep-konsep dari kajian literatur (grounded theo$r y$ ) sehingga argumen yang dihasilkan memiliki dasar yang kuat dan mengurangi bias yang ada.

\section{HASIL DAN PEMBAHASAN}

Analisis Fungsional pada Kasus Adaro Indonesia dan Coaltrade serta Kaitannya terhadap Kewajaran Skema Transfer Pricing

Analisis fungsional merupakan sebuah landasan dalam setiap analisis kewajaran harga (Prescott-Haar, 2008). Selain disyaratkan oleh PER-32 untuk mengungkapkan kesesuaian metode transfer pricing dan memberikan dasar untuk perbandingan, penggunaan analisis fungsional juga berguna untuk mendapatkan suatu hasil telaahan lengkap dan menyeluruh atas rantai atau alur dari suatu transaksi dengan pihak berelasi. Analisis fungsional pada dasarnya melibatkan tiga aspek yaitu fungsi yang dijalankan, aspek yang dipergunakan, serta risiko yang ditanggung oleh setiap entitas yang terlibat (Irawan, 2013). Analisis ketiga aspek ini berujung pada klasifikasi karakterisasi usaha ke dalam tiga bentuk utama: manufaktur, distributor, atau penyedia jasa dimana masing-masing model bisnis memiliki tingkat margin laba, kepemilikan barang, dan risiko bisnis yang berbeda (Przysuski dan Lalapet, 2005). Dalam struktur usaha konglomerasi, karakterisasi usaha yang mencakup tiga aspek analisis fungsional tersebut telah ditentukan di awal karena setiap entitas dalam grup konglomerasi telah mempunyai penugasannya masing-masing. Maka dari itu, langkah pertama yang harus dilakukan adalah mengidentifikasi struktur korporasi grup usaha dan seluruh entitas yang terlibat dalam kesatuan supply chain untuk mendapatkan gambaran awal dari fungsi atau kontribusi yang dijalankan masing-masing entitas (Huibregtse, Verdoner, dan Welvaert, 2009).

Dari struktur organisasi Adaro Energy seperti pada gambar 1 dibawah, dapat diidentifikasi bahwa struktur organisasi Adaro Energy berbentuk korporasi dengan Adaro Energy sendiri sebagai organisasi induk dan sebuah holding company. Karena keterbatasan perannya sebagai holding company, Adaro Energy dapat dikatakan tidak terlibat secara langsung dalam skema transfer pricing penjualan batu bara ke Singapura. Hal ini dikarenakan penerima batu bara dari Indonesia tersebut adalah Coaltrade Services International Pte.Ltd, perusahaan trading dan distribusi yang berbasis di Singapura yang memperdagangkan batubara yang dibeli dari pihak ketiga, menyediakan campuran batubara dan Envirocoal yang bersumber langsung dari Adaro Indonesia (Adaro Energy, 2009). Laba Coaltrade berasal dari margin antara harga beli dan harga jual batu bara tersebut dan dari komisi atas penjualan apabila Coaltrade berperan sebagai agen penjualan (Global Witness, 2019). Di sisi lain, Envirocoal yang diperdagangkan oleh Coaltrade bersumber dari PT Adaro Indonesia sehingga pihak berelasi yang menjual batu baranya kepada Coaltrade adalah PT Adaro Indonesia, sebuah perusahaan penambang batu bara yang menambang dari area sumber daya di kabupaten Tanjung, Provinsi Kalimantan Selatan, Indonesia berdasarkan PKP2B dengan Pemerintah Indonesia hingga tahun 2022 (Adaro Energy, 2009). Dapat disimpulkan bahwa pihak yang terlibat secara langsung dalam skema transfer pricing ini adalah Adaro Indonesia dan Coaltrade yang dibawahi oleh PT Alam Tri Abadi.

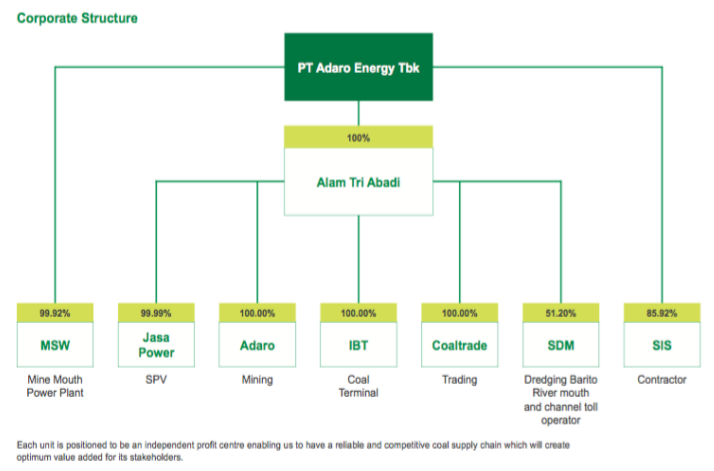

\section{Gambar 1. Struktur Korporasi Adaro Energy}

Setelah identifikasi pihak yang terlibat dalam skema transfer pricing, entitas yang terlibat tersebut diklasifikasikan ke dalam tiga bentuk karakterisasi usaha utama: manufaktur, distributor, atau penyedia jasa dimana masing-masing klasifikasi usaha 
memiliki tingkat margin laba, kepemilikan barang, dan risiko bisnis yang berbeda (Przysuski dan Lalapet, 2005). Mengingat struktur korporasi Adaro Energy yang berbentuk konglomerasi, pengklasifikasian karakterisasi usaha juga dipermudah karena karena setiap entitas telah memiliki penugasannya masing-masing dan penugasan tersebut diungkapkan dalam struktur organisasi dalam laporan tahunan entitas induk seperti pada gambar 1. Menurut struktur korporasi tersebut, Coaltrade telah diidentifikasi dan ditugaskan sebagai perusahaan trading batu bara dan Adaro Indonesia telah diidentifikasi dan ditugaskan sebagai perusahaan penambang batu bara. Dalam pengklasifikasian karakterisasi usahanya, Coaltrade diklasifikasikan sebagai distributor sedangkan Adaro Indonesia diklasifikasikan sebagai manufaktur karena kapasitas dan tugasnya untuk menambang, memproses, dan menggunakan merk dagangnya yaitu Envirocoal. Pengklasifikasian usaha ini penting karena setiap klasifikasi bisnis memiliki tingkat margin laba, kepemilikan barang, dan risiko bisnis yang berbeda yang tentunya akan sangat berpengaruh dalam penentuan kompensasi wajar atas barang/jasa yang disediakan oleh fungsi tersebut.

Selanjutnya, klasifikasi bisnis yang ada tersebut dibagi lagi ke dalam beberapa jenis sesuai dengan kompleksitas fungsi yang dijalankan oleh sebuah entitas. Karena PT Adaro Indonesia termasuk dalam usaha manufaktur, klasifikasi usaha tersebut dibagi lagi menjadi empat skema berdasarkan kompleksitas peran yang dijalankan yaitu: toll manufacturer, contract manufacturer, licensed manufacturer, dan fully-fledged manufacturer (Irawan, 2013). Pembagian klasifikasi ini ada berdasarkan besaran risiko usaha, hak atas legalitas kepemilikan barang, penggunaan aset tidak berwujud, dll dimana toll manufacturer berada di posisi terendah dan fully-fledged manufacturer berada di posisi puncak dalam skema pembagian klasifikasi tersebut. Dalam skema transfer pricing ini, PT Adaro Indonesia dapat diklasifikasikan sebagai sebuah fully-fledged manufacturer karena PT Adaro Indonesia bertanggung jawab atas seluruh proses bisnis yang terlibat, mulai dari manajemen, penelitian dan pengembangan, penambangan batu bara, pemrosesan batu bara, pemasaran, penjualan, logistik, serta keuangan dan administrasi (Adaro Energy, 2009). Sebagai sebuah fully-fledged manufacturer, PT Adaro Indonesia menanggung seluruh resiko dari proses bisnis yang bersangkutan dan bertanggung jawab atas legalitas kepemilikan barang dan menggunakan aset tidak berwujud berupa merk dagang Envirocoal dalam penjualan batu baranya.

Di sisi lain sebagai sebuah perusahaan yang bergerak di bidang usaha distribusi, bidang usaha Coaltrade juga dapat di bagi lagi menjadi beberapa klasifikasi diantaranya: sales representative/sales agent (agen penjualan) dan full-risk distributor. Dalam hal ini, perusahaan yang bergerak dalam fungsi agen penjualan/sales agent terpapar risiko usaha yang lebih sedikit dibandingkan dengan perusahaan yang mengasumsikan fungsi full-risk distributor (Irawan, 2013). Tentunya, hal ini juga akan berdampak pada tingkat kompensasi atau profit margin yang diharapkan dari operasi bisnisnya dimana full-risk distributor memiliki tingkat laba atau kompensasi yang lebih besar atas tanggung jawab dan resiko yang harus ditanggungnya. Pada skema transfer pricing ini, Coaltrade Services International Pte. Ltd dapat diklasifikasikan kedalam bentuk full-risk distributor, model bisnis bagi entitas yang melakukan jual beli dari pihak afiliasi dan pihak ketiga dan bertanggung jawab penuh atas pengelolaan persediaan, logistik, aktivitas pemasaran, serta menanggung semua resiko yang terkait dengan risiko persediaan, risiko pasar, dan risiko gagal tagih (Irawan, 2013). Hal ini dikarenakan definisi peran dari Coaltrade sendiri yang memperdagangkan batubara yang dibeli dari pihak ketiga, dan menyediakan campuran batubara dan Envirocoal yang bersumber langsung dari Adaro Indonesia (Adaro Energy, 2009) dimana Coaltrade melakukan aktivitas jual beli dan mengasumsikan legalitas kepemilikan barang (termasuk campuran batu bara dan Envirocoal yang diperdagangkan) yang tentu saja akan berakibat pada Coaltrade terpapar risiko dari kegiatan operasional tersebut.

Asumsi kedua peran fungsional tersebut, baik Coaltrade maupun Adaro Indonesia berada pada posisi puncak dalam klasifikasi usaha masingmasing unit (manufaktur dan distribusi). Meskipun sama-sama berada pada posisi puncak dalam klasemen usahanya, tingkat risiko, tanggung jawab, serta tingkatan laba yang diharapkan kedua fungsi ini berbeda jauh. Hal ini dikarenakan setiap klasifikasi usaha memiliki aktivitas operasi yang berbeda-beda yang tentunya akan membuat tanggung jawab, tingkat laba yang diharapkan, dan paparan risiko usaha berbeda seperti dapat dilihat pada Gambar 2 (Swaneveld, Przysuski, Lalapet, Osoro, dan Paul, 2004). 


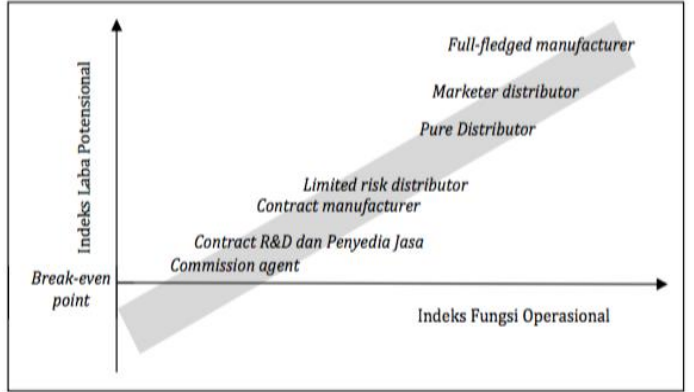

\section{Gambar 2. Kaitan Klasifikasi Usaha dan Tingkat Kompensasi yang Diharapkan}

Entitas yang mengasumsikan peran full-risk distributor (juga disebut sebagai marketer distributor), seperti Coaltrade, terpapar pada tanggung jawab, risiko, dan biaya yang berasal dari kegiatan usaha yang dilakukannya yang terfokus pada pembelian dan penjualan, diantaranya: administrasi umum, biaya terkait dengan aktivitas penjualan, bea dan cukai, biaya terkait dengan aktivitas pemasaran, risiko kredit, garansi/warranty, risiko nilai tukar, product mix pricing, pangsa pasar, dan volume barang yang diperjualbelikan (Irawan, 2013). Meskipun full-risk distributor memiliki legalitas atas kepemilikan barang, menjual barang atas namanya, serta menanggung laba atau rugi dari aktivitas tersebut, entitas yang mengasumsikan peran ini tidak mengubah merk dagang dari barang yang dijual dan, tentu saja, tidak melakukan penambahan nilai yang signifikan terdapat barang dagangannya tersebut. Hal ini berbeda jauh dengan fully-fledged manufacturer, seperti PT Adaro Indonesia, yang melakukan kegiatan pemrosesan material hingga menjadi barang jadi dimana terjadi penambahan nilai yang signifikan terhadap barang. Namun atas aktivitasnya ini juga, sebuah fullyfledged manufacturer terpapar pada tingkatan risiko dan kompensasi yang lebih besar juga. Dalam hal ini, PT Adaro Indonesia sebagai fully-fledged manufacturer juga terpapar resiko dan tanggung jawab lebih daripada fully-fledged manufacturer lainnya karena tanggung jawabnya juga meliputi proses penjualan produknya di dalam negeri, menggunakan merk dagang Envirocoal, dan sifat alamiah harga batu bara sendiri yang memiliki volatilitas tinggi sehingga tingkat kompensasi yang diharapkannya meningkat secara eksponen juga (Adaro Energy, 2009).

Perbedaan tingkat laba yang diharapkan dari PT Adaro Indonesia, sebagai fully-fledged manufacturer, dan Coaltrade, sebagai full-risk distributor, tentunya juga akan berpengaruh terhadap profitabilitas perusahaan secara keseluruhan dan kontri- businya terhadap grup usaha. Dalam kasus ini, tentu saja sebuah fully-fledged manufacturer seperti Adaro Indonesia memiliki tingkatan profitabilitas dan laba bersih yang lebih tinggi dibandingkan dengan sebuah perusahaan full-risk distributor seperti Coaltrade. Dalam data yang diambil dari laporan tahunan Adaro Energy 2008 (gambar 3), dapat dilihat bahwa Adaro Indonesia, sebagai fullyfledged manufacturer, seharusnya mampu meraup laba bersih jauh lebih tinggi daripada Coaltrade, yang diklasifikasikan hanya sebagai full risk distributor. Namun, perbedaan laba yang signifikan hanya terlihat pada tahun 2008 dimana Adaro sendiri telah mengungkapkan bahwa skema transfer pricing pada tahun tersebut telah disesuaikan, dan Coaltrade tidak lagi berperan sebagai full risk distributor melainkan sebagai sales agent. Seharusnya, perbedaan tingkat profitabilitas yang signifikan antara dua klasifikasi model usaha yang berbeda akan mencerminkan bahwa analisis fungsional telah dilakukan secara tepat dan transaksi afiliasi telah mencerminkan harga wajar.

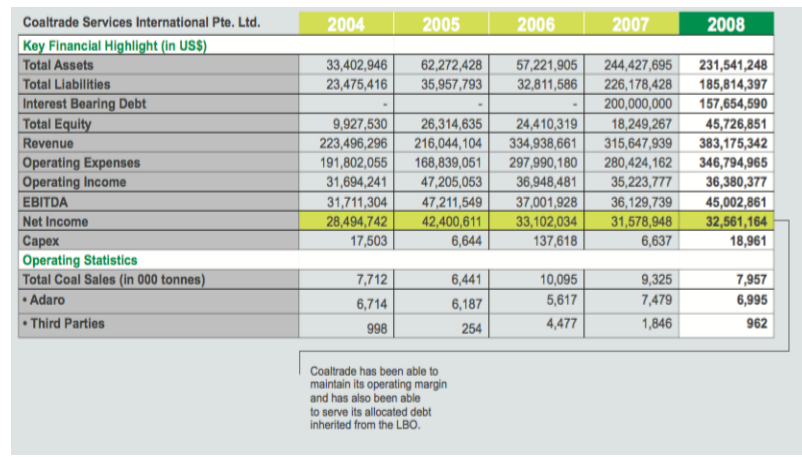

Gambar 3. Sorotan Performa 5 Tahunan PT. Adaro Indonesia (2004-2008)

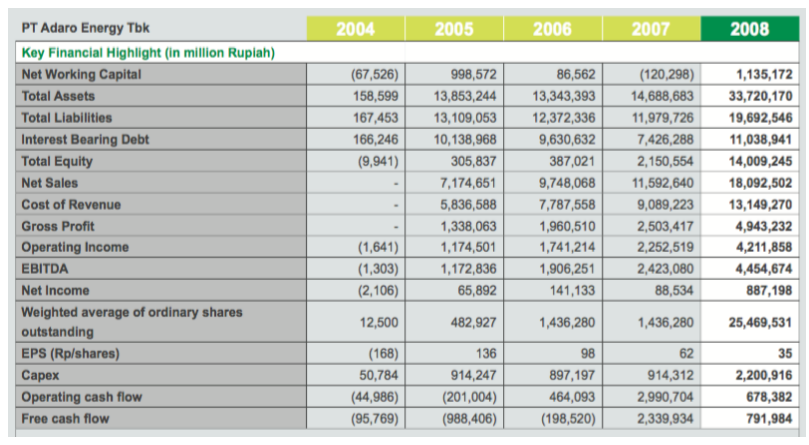

Gambar 4. Sorotan Performa 5 Tahunan Coaltrade (2004-2008)

Dalam kasus sebaliknya, seperti yang tercermin pada performa keuangan Adaro Indonesia dan Coaltrade pada tahun 2004-2007, indikasi kompensasi harga yang tidak wajar dalam transaksi afiliasi 
dapat tercermin dalam profitabilitas perusahaan apabila tingkatan nilai laba ini terbalik atau tidak mencerminkan perbedaan yang signifikan. Dalam kasus ini, Coaltrade, perusahaan full-risk distributor, khususnya pada tahun 2004-2005 meraup laba yang sedikit lebih kecil, dan bahkan lebih besar secara nilai dan tingkatan laba berbanding asetnya (ROA) daripada PT Adaro Indonesia, sebuah fullyfledged manufacturer (lihat gambar 3). Menurut analisis fungsional, hal ini merupakan indikasi bahwa laba telah dipindahkan dari Indonesia ke Singapura dengan tarif pajak yang lebih kecil. Terlebih lagi, hal ini didukung data laporan keuangan bahwa sebagian besar batu bara yang dijual Coaltrade bersumber dari Adaro Indonesia, yang mengindikasikan pemindahan laba Adaro Indonesia ke Coaltrade di Singapura guna mendapatkan tarif pajak penghasilan yang lebih rendah.

Rupanya Global Witness (2019) mencatat pengungkapan Adaro pada tahun 2008 bahwa DJP telah menyimpulkan bahwa penjualan batu bara ke Coaltrade pada tahun 2004 dan 2005 dilakukan dengan harga yang lebih rendah (Global Witness, 2019). Pengungkapan atas ketidakwajaran skema transfer pricing ini menjelaskan skema profitabilitas yang tidak wajar tersebut dimana Coaltrade meraup laba yang lebih besar daripada Adaro Indonesia, sebuah fully-fledged manufacturer. Dalam kasus skema transfer pricing yang tidak wajar seperti ini, Adaro Indonesia pelu melakukan penyesuaian dan menghitung kembali harga jual batu baranya yang dijual ke Coaltrade hingga mencerminkan harga wajar. Hal ini tentu saja menyebabkan laba yang diterima oleh PT Adaro Indonesia meningkat sehingga harus membayar pajak lebih dan juga membayar denda atas penggelapan pajak di Indonesia.

Analisis fungsional terdiri dari beberapa proses identifikasi. Rangkaian identifikasi analisis fungsional dimulai dari identifikasi pihak yang terlibat, identifikasi penggunaan perspektif analisis, identifikasi proses bisnis relevan atas risiko dan penggunaan aset, serta pengklasifikasian model bisnis. Setiap bagian dari proses ini memiliki kaitan yang erat antara satu dengan yang lain dan berhubungan terhadap kewajaran perolehan laba kompensasi atas aktivitas yang dilakukannya. Dalam hal ini, analisis fungsional pada dasarnya mampu memberikan gambaran tingkatan kompensasi yang seharusnya diterima oleh suatu entitas atas kontribusi dan risiko yang dialaminya dalam suatu transaksi afiliasi. Analisis fungsional ini akan mencerminkan kewajaran dalam suatu skema transfer pricing dalam artian ketidakwajaran skema tersebut dapat terindikasi apabila entitas dengan risiko yang lebih rendah mampu meraup laba yang lebih tinggi daripada afiliasinya dengan tingkat paparan risiko yang lebih tinggi.

Perubahan Analisis Fungsional Coaltrade dan Kaitannya terhadap Kewajaran Skema Transfer Pricing

Setelah Adaro Indonesia mengungkapkan penyesuaian yang dilakukannya dan menghitung kembali harga jual batu baranya, Global Witness mencatatkan bahwa ada perubahan terhadap aktivitas operasional pada transaksi afiliasi yang dilakukan oleh Coaltrade (Global Witness, 2019). Dalam kasus perubahan aktivitas operasional seperti yang dilakukan Coaltrade ini, analisis fungsional harus diubah dan dilakukan kembali meskipun perubahan pada analisis fungsional tidak perlu dilakukan secara menyeluruh pada beberapa kasus dimana aktivitas operasional tidak berubah jauh. Namun dalam penelitian ini, analisis fungsional akan dibahas ulang guna mendapatkan pemahaman menyeluruh atas perubahan aktivitas operasional dan dampaknya terhadap analisis fungsional.

Perubahan aktivitas operasionalnya, Coaltrade berperan sebagai sales agent/sales representative (commission agent) yang bertugas untuk melakukan kegiatan penjualan yang meliputi riset atas perilaku pasar, dan melakukan negosiasi atas penjualan batu bara dari Adaro Indonesia dan dari pihak ketiga tanpa adanya perpindahan legalitas barang. Coaltrade, sebagai sales agent, menggunakan asetnya yaitu daftar pelanggan dan terpapar risiko pasar dan risiko pemasaran atas aktivitasnya tersebut. Kompensasi yang diperoleh Coaltrade tidak lagi berupa mark-up atau kenaikan harga melainkan berupa komisi atas penjualan produk yang biasanya berupa persentase atau jumlah yang telah disepakati sebelumnya dalam kontrak. Karena tidak terpapar pada tanggung jawab legalitas kepemilikan barang dan risiko kredit, kompensasi yang diraup Coaltrade lebih kecil daripada kompensasi yang dulu diraupnya ketika berperan sebagai full risk distributor.

Menurut struktur korporasi Adaro Energy yang berbentuk konglomerasi, identifikasi terhadap peran Coaltrade yang awalnya telah diidentifikasi dan ditugaskan sebagai perusahaan trading batu bara tetap tidak berubah karena peran tersebut merupakan peran Coaltrade secara umum dalam value chain grup menggunakan perspektif makro. Namun perubahan aktivitas operasional Coaltrade hanya berjalan pada fungsinya dalam transaksi afiliasi dimana Coaltrade akan lebih ber- 
fokus pada fungsinya sebagai sales agent daripada sebagai full-risk distributor. Dalam hal ini, analis tidak memiliki pilihan perspektif lain selain menggunakan perspektif transaksi terkait dalam menelaah peran dan fungsi Coaltrade dalam transaksi afiliasi secara spesifik. Hal ini dikarenakan Coaltrade sedikit menyimpang dari fungsi umumnya dan harus analisis fungsionalnya harus menggunakan perspektif transaksi terkait (Irawan, 2013). Sebagai sebuah entitas yang menjalankan fungsi sales agent, Coaltrade memperoleh komisi dari penjualan batu bara yang diperolehnya dari pihak ketiga dan Adaro Indoensia (berupa Envirocoal). Namun sebagai sales agent, Coaltrade tidak boleh mengasumsikan kepemilikan legalitas barang yang dijualnya tersebut karena risiko usaha sales agent tidak mencakup legalitas kepemilikan barang (Irawan, 2013).

Dalam pengklasifikasian model usahanya, Coaltrade masih tetap diklasifikasikan kedalam model usaha distributor, hanya saja Coaltrade sekarang menjalankan fungsi sales agent/commission agent. Entitas yang menjalankan fungsi sales agent ini hanya menjalankan tugas negosiasi dan aktivitas lainnya yang terkait hanya dengan penjualan produk. Dalam hal ini, Coaltrade menggunakan daftar pelanggan sebagai asetnya dan terpapar risiko pasar dan risiko pemasaran atas aktivitasnya tersebut. Tentu saja karena Coaltrade hanya menjalankan peran dan risiko yang lebih terbatas dibandingkan ketika Coaltrade menjalankan fungsi full risk distributor, tingkatan laba atau kompensasi yang didapat Coaltrade dari aktivitas operasional dalam transaksi afiliasinya pun akan berkurang. Di sisi lain, hal ini akan menyebabkan laba yang diperoleh Adaro Indonesia meningkat dibandingkan ketika dia harus menjual kepada Coaltrade sebagai full risk distributor. Perubahan analisis fungsional ini terefleksikan juga pada laporan keuangannya dimana laba bersih dari Adaro Indonesia terlihat naik signifikan dan berbeda jauh dengan Coaltrade yang mengasumsikan peran sales agent. Pada tahun 2008, terlihat bahwa Adaro Indonesia meraup laba bersih \$ 163 juta sedangkan Coaltrade meraup laba bersih \$ 32 juta. Perbedaan signifikan yang cukup jauh antara laba bersih keduanya ini mencerminkan bahwa analisis fungsional telah dilakukan dengan tepat dan harga transfer pricing pada transaksi afiliasi sedikit banyak mengindikasikan kewajaran. Perubahan analisis fungsional dalam hal ini berdampak langsung dengan perubahan gambaran tingkatan kompensasi yang diterima oleh entitas tersebut. Dalam hal ini, kewajaran transfer pricing akan tetap terindikasi apabila analisis fungsional tersebut dilakukan dengan tepat.

\section{SIMPULAN}

Penelitian ini ditujukan untuk menjelaskan analisis fungsional dan kaitannya dalam menelaah aspek kewajaran transfer pricing melalui analisis kasus kontemporer di bidang studi transfer pricing. Selain itu, penelitian ini juga menawarkan kebaharuan dalam studi transfer pricing dimana kajian dalam penelitian ini berfokus pada analisis fungsional, sebuah topik yang masih tergolong jarang dalam studi transfer pricing di Indonesia. Dalam melakukan analisisnya, peneliti menggunakan strategi analisis data sekunder dimana data sekunder yang ada dikaji lebih lanjut guna mengevaluasi atau menelaah kembali hasil yang telah ada. Dalam melakukan analisis data sekunder, analisis dan pembentukan argumen didukung data faktual berupa laporan keuangan Adaro Energy sendiri untuk tahun-tahun yang bersangkutan dan juga konsep-konsep dari kajian literatur (grounded theory) sehingga argumen yang dihasilkan memiliki dasar yang kuat dan mengurangi bias yang ada.

Proses analisis fungsional pada umumnya melibatkan beberapa proses identifikasi dan analisis. Proses identifikasi dan analisis tersebut diantaranya: identifikasi entitas yang terlibat, identifikasi perspektif analisis fungsional, identifikasi proses bisnis relevan terkait dengan risiko dan penggunaan aset dalam transaksi afiliasi terkait, dan pengklasifikasian entitas ke dalam beberapa model bisnis yang sesuai dengan aktivitas operasionalnya, legalitas kepemilikan barang, penggunaan aset, dan tingkat paparan risiko yang dialami. Analisis fungsional ini berujung pada klasifikasi model bisnis serta gambaran tentang tingkaat kompensasi wajar yang dihasilkan dari entitas tersebut.

Kasus transfer pricing melibatkan Adaro Indonesia, sebagai fully-fledged manufacturer, dan Coaltrade sebagai full risk distributor, batu bara dengan merk dagang dijual oleh Adaro Indonesia pada Coaltrade yang berbasis di Singapura. Dalam hal ini, Adaro Indonesia memanfaatkan kapasitasnya sebagai fully-fledged manufacturer dan menggunakan asetnya dalam memproses batu bara hingga menjadi sebuah produk yang dibubuhi merk dagang - aset tidak berwujud - Envirocoal guna mendapatkan kompensasi dari harga jual batu bara tersebut kepada Coaltrade. Di sisi lain, Coaltrade sebagai full risk distributor menggunakan aset keuangannya untuk membeli legalitas kepemilikan barang dari batu bara Envirocoal ter- 
sebut dan menjualnya kembali dengan harga yang telah dinaikkan guna mendapatkan kompensasi atas penggunaan aset dan risiko yang terpapar padanya.

Namun, peninjauan lebih lanjut mengindikasikan bahwa seharusnya tingkat laba yang diperoleh Adaro Indonesia jauh lebih besar daripada Coaltrade karena tanggung jawab dan risikonya sebagai fully-fledged manufacturer yang lebih besar dibandingkan Coaltrade mengasumsikan fungsi full risk distributor. Kasus dimana laba perusahaan dengan tingkatan risiko yang lebih rendah namun memperoleh tingkatan laba bersih yang lebih tinggi mengindikasikan bahwa tingkatan kompensasi yang diterima entitas tersebut tidak wajar dan mencerminkan sebuah praktik transfer pricing yang tidak wajar juga dan dapat dibawa ke ranah penggelapan pajak. Dalam hal ini, analisis fungsional memberikan gambaran tentang tingkat kompensasi wajar yang diterima oleh suatu entitas yang menjalankan suatu fungsi dalam transaksi afiliasinya dimana kewajaran skema transfer pricing sedikit banyak akan terindikasi dari sana. Penelitian lebih lanjut dapat membahaas analisis fungsional ini dengan metode lainnya yang lebih memungkinkan interaksi antara peneliti dan subjek penelitian, misalnya dengan menggunakan studi kasus guna mendapatkan dana kualitatif transfer pricing yang bergantung pada social situation sehingga penelitian dapat memperoleh data yang lebih luas baik secara kualitas maupun secara kuantitas.

\section{REFERENCES}

Adaro Energy. (2009). Laporan Tahunan 2009 PT. Adaro Energy Tbk. Didapatkan dari http:/ / www.adaro.com/files/news/berkas/1 08/Laporan \%20Tahunan\% 202009.pdf.

Arikunto, S. (2016). Prosedur Penelitian Suatu Pendekatan Praktik. Jakarta: Rineka Cipta.

Arnold, B., dan McIntyre, M. (2002). International Tax Primer. New York: Kluwer Law International.

Butterworths. (1997). Business and Law Dictionary. Sidney: Butterworths.

Darussalam, Septriadi, D., dan Kristiaji, B. B. (2013). Pendahuluan: Ide, Strategi, dan Panduan Praktis. Dalam Darussalam, Septriadi, D., dan Kristiaji, B. B. (Ed). Transfer Pricing: Ide, Strategi, dan Panduan Praktis dalam Perspektif Pajak Internasional (h. 3-34). Jakarta: Danny Darussalam Tax Center.

Darussalam, dan Ngantung. Y. W., (2013). Transfer Pricing: Prinsip Hukum Perpajakan Inter- nasional. Dalam Darussalam, Septriadi, D., dan Kristiaji, B. (Ed). Transfer Pricing: Ide, Strategi, dan Panduan Praktis dalam Perspektif Pajak Internasional (h. 61-86). Jakarta: Danny Darussalam Tax Center.

Dewi, R., dan Mustikasari, E. (2020). Analisis Penangangan Manipulasi Transfer Pricing Perpajakan dalam Menjawab Tantangan Global. EJurnal Akuntansi, 30(2), 460-473.

Ernst and Young Global. (2018). Worldwide Transfer Pricing Reference Guide 2017-2018. Didapatkan dari https://www.ey.com/en_gl/taxguides/worldwide-transfer-pricing-referenceguide-2020.

Feinschreiber, R. dan Kent, M. (2012). Asia-Pacific Transfer Pricing Handbook. Singapore: John Wiley and Sons Singapore Pte. Ltd.

Global Witness. (2019). Indonesia's Shifting Coal Money: How Vast Sums Have Been Move Offshore and Out of Sight Part 3: Taxing Times for Adaro. Didapat dari https://www.globalwitness.org/en/campaig ns/oil-gas-and-mining/indonesias-shiftingcoal-money-3-taxing-times-for-adaro/.

Horst, T. (1971). Theory of the Multinational Firm: Optimal Behaviour Under Different Tariff and Tax Rates. Journal of Political Economy, 79(5), 1059-1072.

Huda, M., Nugraheni, N., dan Kamarudin, K. (2017). The Problem of Transfer Pricing in Indonesia Taxation System. International Journal of Economics and Financial Issues, 7(4), 139-143.

Huibregtse, S., Verdoner, L., dan Welvaert, J., (2009). Transfer Pricing Handbook. Amsterdam: Transfer Pricing Associates.

Irawan, R. (2013). Analisis Fungsional. Dalam Darussalam., Septriadi, D., dan Kristiaji, B. B. (Ed). Transfer Pricing: Ide, Strategi, dan Panduan Praktis dalam Perspektif Pajak Internasional (h. 107-132). Jakarta: Danny Darussalam Tax Center.

Irawan, R., Febby, C., dan Kristiaji, B. (2013). Analisis Kesebandingan. Dalam Darussalam., Septriadi, D., dan Kristiaji, B. B. (Ed). Transfer Pricing: Ide, Strategi, dan Panduan Praktis dalam Perspektif Pajak Internasional (h. 133-153) Jakarta: Danny Darussalam Tax Center.

Lebowitz, B. (2000). Transfer Pricing and The End of International Taxation. Transfer Pricing Report, 9(61), 1-11.

Mehafdi, M. (2000). The Ethics of International Transfer Pricing. Journal of Business Ethics, 28(4), 365-381. 
Moleong, L. (2017). Metode Penelitian Kualitatif (Edisi ke-30). Jakarta: Remaja Rosdakarya.

Peraturan Direktur Jenderal Pajak Nomor PER-32. (2011). Perubahan atas Peraturan Direktur Jenderal Pajak Nomor PER-043/PJ/2010 Tentang Penerapan Prinsip Kewajaran dan Kelaziman Usaha dalam Transaksi antara Wajib Pajak dengan Pihak yang Mempunyai Hubungan Istimewa. Didapatkan dari https:// perpajakan.ddtc.co.id/peraturanpajak/read/peraturan-dirjen-pajak-per32pj2011.

Peraturan Menteri Keuangan Indonesia Nomor 213/ PMK.03 / 2016. (2016). Jenis Dokumen dan/atau Informasi Tambahan yang Wajib Disimpan oleh Wajib Pajak yang Melakukan Transaksi dengan Para Pihak yang Mempunyai Hubungan Istimewa dan Tata Cara Pengelolaannya. Didapatkan dari https://jdih.kemenkeu.go.id/fullText/2016/2 13 PMK.03 2016Per.pdf.

Prescott-Haar, L. (2008). Practical Issues in a Carrying Out and Implementing a Transfer Pricing Study. Dalam Green, G. (Ed). Transfer Pricing Manual (h. 133-167). London: BNA International.

Przysuski, M. dan Lalapet, S. (2005). Appropriate Canadian Transfer Pricing Documentation. Tax Notes International, October, 26(39), 55-88.

Saraswati, M., Saifi, dan Dwiatmanto, M. (2014). Evaluasi Kewajaran Harga dan Kesesuaian Metode Transfer Pricing dengan PER Dirjen Pajak Nomor PER-32/PJ/2011 (Studi kasus pada PT. Mertex Indonesia). Jurnal Mahasiswa Perpajakan, 3(1), 1-9.

Setiawan, H. (2014). Transfer Pricing dan Resikonya terhadap Penerimaan Negara. Didapat dari https://www.kemenkeu.go.id/sites/default/ files/2014_kajian_pprf_transfer\%20pricing $\% 20$ dan\%20risikonya \%20terhadap\%20penerimaan \%20negara.pdf, 01 Juli 2020, pukul 12.45 WIB.

Swaneveld. H., Przysuski. M., Lalapet. S., Osoro. C., dan Paul. P. (2004). Transfer Pricing and Characterisation of Multinational Enterprise Operations with a Focus on Canada and the US. Tax Notes International, 34(7), 743-763.

Undang-Undang Republik Indonesia Nomor 36. (2008). Perubahan Keempat atas Undang-Undang Nomor 7 Tahun 1983 Tentang Pajak Penghasilan. Didapatkan dari https://jdih.esdm.go.id/peraturan/UU\%20N o. $\% 2036 \% 20$ Thn $\% 202008$.pdf.
Van den Hurk, H. (2014). Starbucks versus The People. Bulletin for International Taxation, 68(1), 27-34. 